\title{
Influence of the Baltic Sea water on Klaipeda seaport hydrotechnical structures
}

\author{
Ramune Lebedeva, Vilma Vaicekauskiene, VGTU, Department of Structural Engineering and \\ Klaipeda State University of Applied Sciences
}

\begin{abstract}
Hydrotechnical constructions in Klaipeda Seaport are constantly affected by the Baltic Sea environment (humidity, temperature changes, freezing and thawing effects, etc.). Hydrotechnical concrete is negatively affected by the Baltic Sea water, consisting of certain amounts of salts, highly repetitive moistening and drying (sorption and desorption) processes. Hydrotechnical concrete is characterized by capillary porosity, which is typical of Klaipeda Seaport hydrotechnical structures - quays, because they constantly rise in sea water at different levels of the surface. The aim of the study was to determine the influence of mineral additives on the type of gum, regulating sorbent parameters. The experimental results obtained will provide an opportunity to predict the durability of hydraulic concrete according to its sorption characteristics and damage to corrosion.

Keywords: The Baltic Sea water, hydrotechnical structures, hydrotechnical concrete, active mineral additives, durability.
\end{abstract}

\section{Introduction}

Baltic Sea water is affected by reinforced concrete structures used in the seafront of Klaipeda Seaport (quays, piers), on the banks of the coastal rivers and on the Curonian Spit. The current state of these hydrotechnical structures shows that during their operation in Klaipeda Seaport the waters there are damaging, especially on the surface, and big money is spent on repairing the hydrotechnical engineering structures. This study explores the conditions of exploitation of hydrotechnical reinforced concrete structures under the influence of the Baltic Sea water, researching the effect of the Baltic Sea water on the decomposition of concrete

and investigates active mineral additives to be used to modify cement mixtures, making them resistant to the impact of Baltic Sea water [2]. Demolition of concrete surfaces and corrosion of reinforcement, which occur due to the wetting of concrete with salt water in the Baltic Sea and temperature fluctuations, are typical phenomena in reinforced concrete constructions of hydraulic structures in the Baltic Sea [14], [20]. The results of the research carried out can be applied to the preparation and improvement of the regulatory standards for construction of reinforced concrete structures in the Baltic Sea [12], [23], [27].
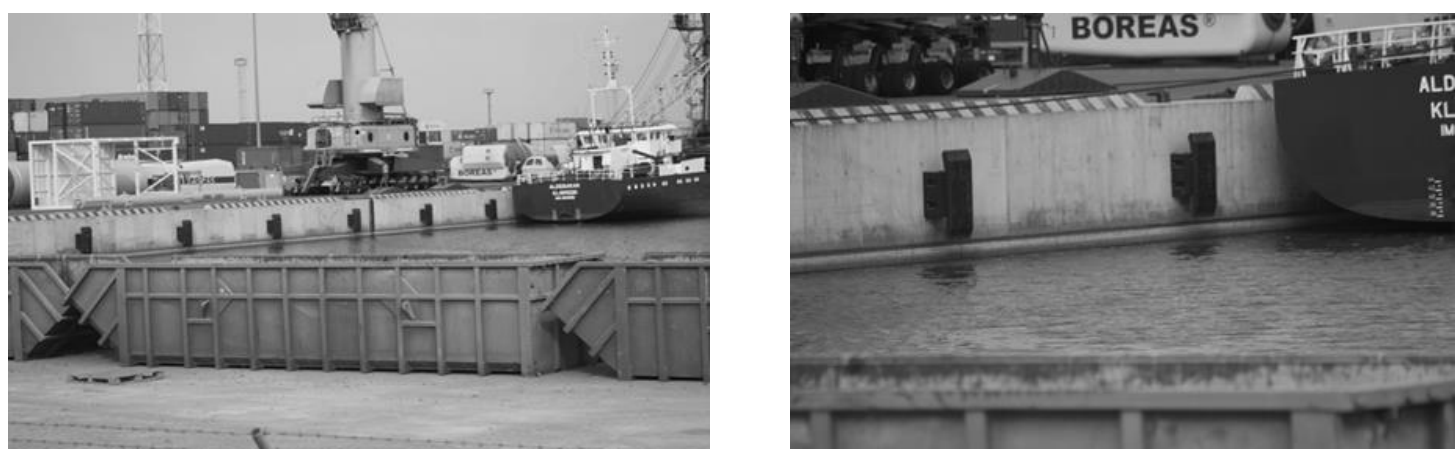

Fig. 1. Klaipeda Seaport Hydrotechnical Building, Constituent Constructions, Corrosion of Hydrotechnical Concrete

Hydrotechnical concrete is a conglomerate structure material characterized by capillary porosity. The hydrophilic concrete capillary moistening through pores is caused by the penetration of Baltic Sea water into the capillaries by which it rises to the top of the reinforced concrete structure [13], [21], [3]. The height level that the Baltic Sea water is able to reach through capillaries depends on the diameter of capillaries in the concrete. Capillary moistening is typical of Klaipeda Seaport's hydrotechnical constructions - berths, piers, moles, because they are constantly exposed to the Baltic Sea water, at different surface levels [10]. Due to the diffusion process, sea water moves from the moist concrete surface to a damp surface because of its specific chemical composition, causing certain corrosion processes in the cement stone [14], [17], [25]. 
The aquatorium of Klaipeda Seaport, according to its climatic conditions belongs to the western climate region of Lithuania [9]. A steady rise in the ocean level, changes in rainfall and stronger wind gusts cause more and more extreme natural phenomena storms in the area of Klaipeda Seaport. Studies in the territory of Lithuania on air temperature, rainfall, and water level changes show that the climate has changed since 1971 and it negatively affects the hydraulic concrete. As the amount of precipitation increases and the Baltic Sea level rises, the water level in Klaipeda Seaport may rise to $0.5-1.0 \mathrm{~m}$, which will affect the hydraulic concrete used in Klaipeda Seaport [8].

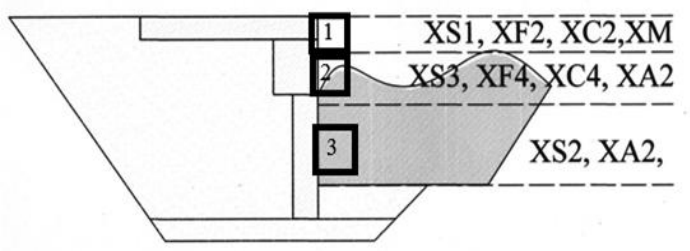

Fig. 2. Zones of operation of hydrotechnical concrete

Taking into account the deteriorating factors of concrete during the operation period, three different zones of operation of hydrotechnical concrete presented in Figure 2 can be distinguished:

- the first one above water level in which the concrete is not impregnated by the capillary absorption of Baltic Sea water is classified as XS1, $\mathrm{XF} 2$, XC2 environmental impact classes, where hydrocarbon concrete carbonization occurs, the corrosion of the reinforcement and the surface degradation due to the freezing and thawing cycles;

- the second is in the zone of water level where concrete is permanently dipped in sea water and cyclically exposed to possible negative temperatures (the surface being in the air) - thus classified as XS3, $\mathrm{XF} 4, \mathrm{XC} 4, \mathrm{XA} 2$ environmental impact classes, in which the hydrotechnical concrete must be resistant to the freezing and thawing cycles together with salts, have low conductivity to chlorides due to corrosion of reinforcement, must be resistant to the carbonization process and chemicals such as resistant to chlorides, sulphates and other compounds in the waters of the Baltic Sea;

- the third zone under water where the concrete is continuously in the Baltic Sea and is chemically exposed to the Baltic Sea water and corrosion of the reinforcement due to the intensive chloride diffusion processes in concrete is classified as XS2, XA2 environmental impact classes, in which the hydraulic concrete is to be resistant to sulphate corrosion and low conductivity for chlorides [6].

Hydrotechnical concrete is negatively affected by the Baltic Sea water, which consists of certain amounts of salts. It is also affected by repeated moistening and drying (sorption) processes. The effect of these factors is determined by the physical and chemical concrete corrosion [17], [32]. Hydrotechnical concrete structures must be resistant to the effects of moisture, penetration of sea water into further layers of concrete and corrosion caused by it. Hydrotechnical concrete, exploited by the impact of the Baltic Sea water is subjected to one of the most important types of corrosion - carbonisation, which depends on $\mathrm{CO}_{2}$ diffusion in concrete and $\mathrm{CO}_{2}$ reactivity with concrete hydration products. The main factors determining the carbonisation rate are the amount of binders in concrete, the ratio of water and binder in concrete, the degree of the hydration of cement, $\mathrm{CO}_{2}$ and relative humidity in concrete [19], [26], [27]

Mineral additives are used to modify concrete composition by improving the technological properties of the mixtures and the properties and durability of hardened concrete. Mineral additives in the concrete mix increase water impermeability and resistance to aggressive environmental influences [15], [16], [13]. Many sources of literature show that granular blast furnace slag, which is required by the European Standard LST EN 197-1, increase Portland cement's resistance to the effect of the marine environment [5]. The studies of some authors discuss the effect of coal ash on improving concrete properties by optimizing the composition of concrete by replacing the corresponding cement content with coal ash [2], [8], [13], [21]. Scientists have found that there is no optimum amount of ash that we can apply to all concrete mixtures, depending not only on the ash itself, but also on the composition and requirements of cement stone and concrete. Summarizing the results of some researchers, the optimum amount of lacquer ash rises up to 25\% [13].

Many scientific papers point to the positive influence of $\mathrm{SiO}_{2}$ micro dust as an active mineral additive to concrete: it modifies the microstructure of concrete, makes it more homogeneous, reduces the number of large pores, reduces water vapour permeability and increases the strength of concrete, especially using plastics. Researchers have confirmed that $\mathrm{SiO}_{2}$ micro dust as an active mineral additive increases the compressive strength and durability of concrete, improves its microstructure, thereby increasing the resistance of concrete to aggressive environments [4]. 


\section{Used materials}

Portland cement CEM I 42.5N, slag Portland cement - CEM II / A-S 42.5N, limestone Portland cement - CEM II / A-LL 42.5N and slag cement CEM III / B $32.5 \mathrm{~N}$ were used in the research. In assessing the properties of these Portland cements, it has been observed that slag cement is less active during the first days of curing. After analyzing the composition of the cement, the amount of mineral additives added to the composition is as follows: Portland cement CEM I 42.5N - 0\% slag amount, clinker content from $95 \%$ to $100 \%$, slag cement CEM II / AS $42.5 \mathrm{~N}$ is 6 to $20 \%$ CEM II / A-LL $42.5 \mathrm{~N}$ contains from 6 to $20 \%$ of the amount of slag, the amount of clinker from $80 \%$ to $94 \%$, the addition of blast furnace slag in slag cement CEM III / B (from 80 to $94 \%$ ), the addition of blast furnace slag to slag cement CEM III / B $32.5 \mathrm{~N}$ is about $80 \%$ and the limestone content is up to $20 \%$. ([17]). Different amounts of slag were chosen, or concrete with no added mineral content has no strict requirements for the composition of the cement: $\mathrm{C}_{3} \mathrm{~S}$ and $\mathrm{C}_{3} \mathrm{~A}+\mathrm{C}_{4} \mathrm{AF}$ quantities are not customizable, and the amount of $\mathrm{C}_{3} \mathrm{~A}$ in clinker can sometimes reach $8 \%$ or more. The FLUXER GT3 superplasticizer was used, which was modified by the new generation of polycarboxylate and synthetic air-containing Adhesive Centrament Air 202, 0/4 mm fraction sand, granite 2/8 and 11/16 fractional rubble, and modified for composition modifications to water and / cement ratio, and in several compositions the type and percentage of cement was changed. Salt water corresponding to the chemical composition of the Baltic Sea water was used in the study.

\section{Methodology of investigation}

Concrete cubes $(100 \times 100 \times 100 \mathrm{~mm})$ were formed for the investigation of water resistance of the
Baltic Sea from the hydraulic concrete. After hardening (28 days) of concrete, samples were cut in half. Concrete samples were tested to measure the viability of the samples in the presence of saline solution in accordance with the chemical composition of the Baltic Sea. The prepared samples of hydrotechnical concrete were weighed on a scale, placed in an oven, and dried at $100^{\circ} \mathrm{C}$, after a day, the samples were tested by immersing the samples half-way in the solution, measuring the capillary absorption for the first hour every 15 minutes, then every $4 \mathrm{~h}, 8 \mathrm{~h}$, then every one day, 2 days, 7 and 14 days. After 14 days of the test of concrete in a Baltic Sea water solution, capillary immersed measurements were taken, samples of hydrotechnical concrete were completely immersed in a solution which corresponds to the chemical composition of the Baltic Sea water (all completely cut cubes) and washed for 2 days. After 2 days of immersion of the concrete samples, these samples were dipped in one side in the chemical composition of the Baltic Sea water and the methodology was repeated again from the beginning. The results of the test were estimated to $0.01 \mathrm{~g}$. The results of the study are presented in Figures 4-15. The capillary absorption of the solution of the chemical composition of the Baltic Sea into the hydrothermal concrete is calculated according to the formula given in the standard:

$$
W_{m}=\frac{m_{d}-m_{s}}{m_{s}} \times 100
$$

where:

$\mathrm{W}_{\mathrm{m}}$ - water absorption of concrete sample, \%;

$\mathrm{m}_{\mathrm{d}}$ - mass of the impregnated sample, $\mathrm{kg}$;

$\mathrm{m}_{\mathrm{s}}$ - initial sample mass, $\mathrm{kg}$;

The following equipment was used for testing: weighing scales with a weighing accuracy of $0.1 \mathrm{~g}$, a plastic bath, a thermometer, a stopwatch, a cloth.

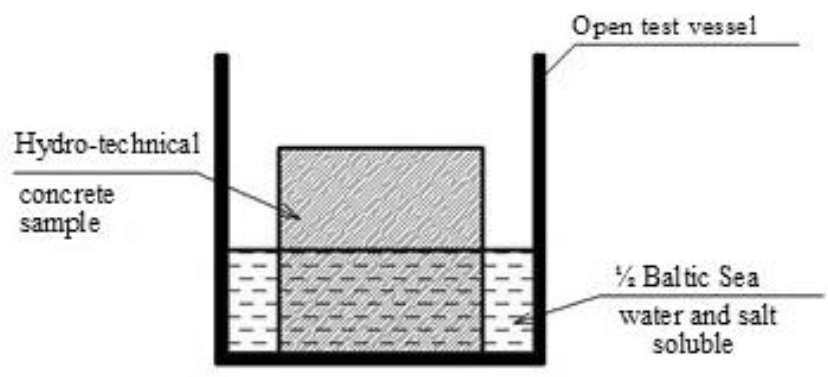

Fig. 3. Sorption Test Scheme 
Components of hydrotechnical concrete used for research on the impact of granular blast furnace slag and rock formations

\begin{tabular}{|l|l|l|l|l|l|l|}
\hline Mixture label & BS0 & BS1 & BS2 & BS3 & BS4 & BL1 \\
\hline Slag, \% & 0 & 17 & 35 & 49 & 70 & $17^{*}$ \\
\hline CEM I 42.5 N, kg & 433 & - & 216 & 129 & - & - \\
\hline CEM II A/S 42.5 N & - & 433 & - & - & - & - \\
\hline CEM III/B 32.5 N-H(SR) & - & - & 216 & 303 & 433 & - \\
\hline CEM II A/LL 42.5 N & - & - & - & - & - & 433 \\
\hline Granite rubble 2/8, kg & 411 & 411 & 411 & 411 & 411 & 411 \\
\hline Granite chip 11/16, kg & 615 & 615 & 615 & 615 & 615 & 615 \\
\hline Sand 0/4, kg & 754 & 754 & 754 & 754 & 754 & 754 \\
\hline Water, kg & 142 & 142 & 142 & 142 & 142 & 142 \\
\hline Plasticisers, kg & 3.5 & 3.5 & 3.5 & 3.5 & 3.5 & 3.5 \\
\hline Airborne supplement, kg & 0.26 & 0.26 & 0.26 & 0.26 & 0.26 & 0.26 \\
\hline V/C & 0.33 & 0.33 & 0.33 & 0.33 & 0.33 & 0.33 \\
\hline V/R & 0.33 & 0.33 & 0.33 & 0.33 & 0.33 & 0.33 \\
\hline
\end{tabular}

$17 *$ - was not slag, but limestone cement.

Six composites of the hydrotechnical concrete formed with different three cements, which differ in mixture were formed, which are presented in Table 2. composition from the mineral additive, its percentage The hydrotechnical concrete constituents were and the amount of different cement.

TABLE 2

Hydrocarbon Structural hydrocarbon concrete used for research on the influence of coal combustion ash

\begin{tabular}{|l|c|c|c|c|c|}
\hline Mixture label & BV0 & BV1 & BV2 & BV3 & BV4 \\
\hline Ash, \% & 0 & 17 & 35 & 49 & 70 \\
\hline Cement CEM I 42.5 N,kg & 433 & 359 & 281 & 221 & 131 \\
\hline Mineral additive, (of ashes) kg & 0 & 74 & 152 & 212 & 303 \\
\hline Granite rubble 2/8, kg & 411 & 411 & 411 & 411 & 411 \\
\hline Granite chip 11/16, kg & 615 & 615 & 615 & 615 & 615 \\
\hline Sand 0/4, kg & 754 & 754 & 754 & 754 & 754 \\
\hline Water, kg & 142 & 142 & 142 & 142 & 142 \\
\hline Plasticizers, kg & 3.5 & 3.5 & 3.5 & 3.5 & 3.5 \\
\hline Airborne supplement, kg & 0.26 & 0.26 & 0.26 & 0.26 & 0.26 \\
\hline V/C & 0.33 & 0.40 & 0.51 & 0.64 & 1.08 \\
\hline V/R & 0.33 & 0.33 & 0.33 & 0.33 & 0.33 \\
\hline
\end{tabular}

Five compounds of the hydraulic concrete mix were formulated, which are presented in Table 3. These hydrotechnical concrete compounds were formed with 2 different cements, which differ in composition from the mineral additive, by its percentage $(0 \%$ and $17 \%)$. In addition, another mineral additive was introduced: ash, its content ranged from $0 \%$ to $70 \%$, v/c ratio was maintained at
0.33 , and all other parameters remained unchanged from the initial composition of the concrete mix. Different fillers were used to carry out the evaluation of the filler, or forecasting in hydraulic concrete. It has been determined that the properties of concrete depend on the filler, its structure, which influence the durability properties of concrete.

The composition of hydrotechnical concrete used for investigations of $\mathrm{SiO}_{2}$ micro dust

\begin{tabular}{|l|l|l|l|l|l|}
\hline Mixture label & \multicolumn{1}{|c|}{$\begin{array}{c}\text { BVSi } \\
0\end{array}$} & \multicolumn{1}{|c|}{$\begin{array}{c}\text { BVSi } \\
1\end{array}$} & \multicolumn{1}{|c|}{$\begin{array}{c}\text { BVSi } \\
3\end{array}$} & \multicolumn{1}{|c|}{$\begin{array}{c}\text { BVSi } \\
\text { BVSi }\end{array}$} & \multicolumn{1}{c|}{5} \\
\hline $\mathrm{SiO}_{2}, \%$ & 0 & 2 & 4 & 6 & 7 \\
\hline Cement CEM I 42.5 N, kg & 433 & 359 & 345 & 338 & 330 \\
\hline Ash, \% & 17 & 17 & 17 & 17 & 17 \\
\hline $\mathrm{SiO}_{2}, \mathrm{~kg}$ & 0 & 9 & 17 & 26 & 35 \\
\hline Granite rubble 2/8, kg & 411 & 411 & 411 & 411 & 411 \\
\hline Granite chip 11/16, kg & 615 & 615 & 615 & 615 & 615 \\
\hline Sand 0/4, kg & 754 & 754 & 754 & 754 & 754 \\
\hline Water, kg & 142 & 142 & 142 & 142 & 142 \\
\hline Plasticisers, kg & 3.5 & 3.5 & 3.5 & 3.5 & 3.5 \\
\hline Airborne supplement, kg & 0.26 & 0.26 & 0.26 & 0.26 & 0.26 \\
\hline V/C & 0.33 & 0.33 & 0.33 & 0.33 & 0.33 \\
\hline V/R & 0.33 & 0.33 & 0.33 & 0.33 & 0.33 \\
\hline
\end{tabular}




\section{Results of the analysis}

In Figure 4, the samples of hydrotechnical concrete were formed with CEM I 42.5N, CEM II A / S 42.5N and CEM III / B 32.5 N different types of cements containing $0 \%, 17 \%, 70 \%$ granular blast furnace slag additives. These samples with $0 \%, 17 \%$, and $70 \%$ granular blast furnace slag additives were dipped in a saline solution corresponding to the chemical composition of the Baltic Sea water, the composition of which is given in Tables 1, 2 and 3 . The results of sorption in a saline solution of the Baltic Sea with different granular blast furnace slag additives carried out in accordance with the presented method are presented in an impregnated condition state, in a dried state and in a soaked state $(4,5$ and $6)$.

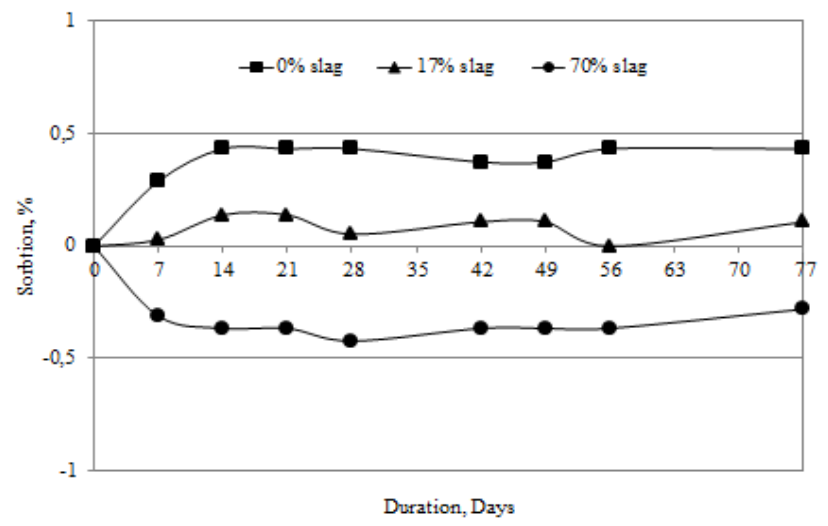

Fig. 4. Testing results of sorption of oversized hydrotechnical concrete with different amounts of slag in cement

In Figure 4, samples were dipped half-way in the water saline solution of the Baltic Sea and left in it for 7 days and the sorption parameters were measured accordingly for 7 days. From Figure 4 it can be seen that the absorption of concrete or solution drying (sorption and desorption) intensively takes up to 14 days and the subsequent monitoring of these processes did not show any changes, therefore further sorption and desorption tests were carried out for up to 14 days. Figure 4 shows the hydrotechnical samples with different types of cements, different amounts of granular blast furnace slag, after 28 days of hardening. The obtained results showed that the hydrotechnical concrete samples were composed of CEM I type cement containing $0 \%$ granular blast furnace slag, the sorption process was carried out, i.e. the salinity of the salt solution increased to $0.5 \%$. Concrete samples with $17 \%$ granular blast furnace slag, i.e. the speed of the CEM II A / S type cement sorption process was equal to the rate of the desorption process and the solution absorbed up to $0.2 \%$.

Concrete samples with $70 \%$ granular blast furnace slag, i.e. The CEM III / B type cement mortar is up to $-0.4 \%$, which means the sample has dried over it.

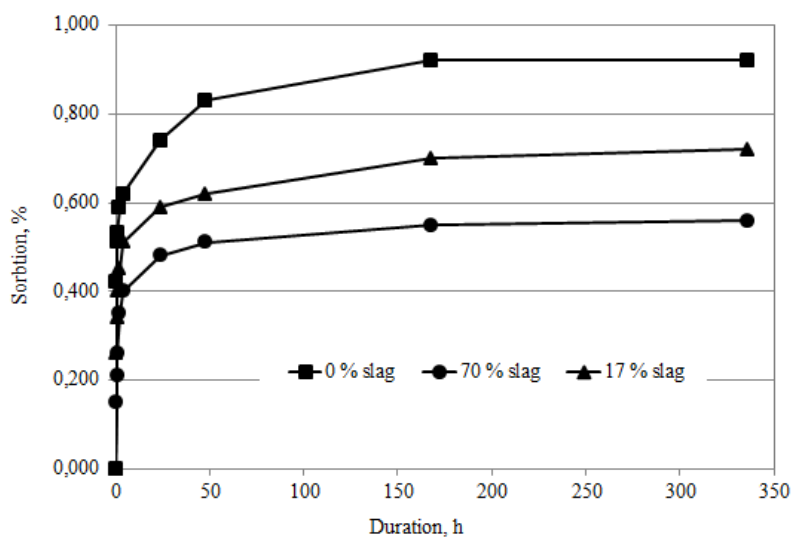

Fig. 5. Results of sorption tests of dried hydrotechnical concrete with different levels of blast furnace slag in cement

In Figure 5, the results of the solidification sorption tests of dried, hydrotechnical concrete samples with different amounts of blast furnace slag after 28 days are presented. The non-slag-free specimens absorbed most of the Baltic Sea water saline solution and kept it in equilibrium after for approximately one week. Cements with $17 \%$ and $70 \%$ blast furnace slag are characterized by lower 
sorption - with a $0 \%$ blast furnace slag additive up to $0.7 \%$ and from $70 \%$ to $0.58 \%$. It can be concluded that a higher amount of blast furnace slag reduces the hydrophobic concrete sorption.

In Figure 6, the results of the hardening sorption tests of impregnated hydrotechnical samples with different amounts of blast furnace slag after 28 days are presented. In this case, desorption processes occur, i.e.evaporation of the salt solution from concrete samples. In the non-slag cement, the lowest desorption is observed, in the $17 \%$ blast furnace slag containing cement, and $70 \%$ in the blast furnace slag cement being the highest. The desorption processes in concrete reduce the amount of water or salt solution and increase its resistance to freezing and thawing effects in wet conditions.

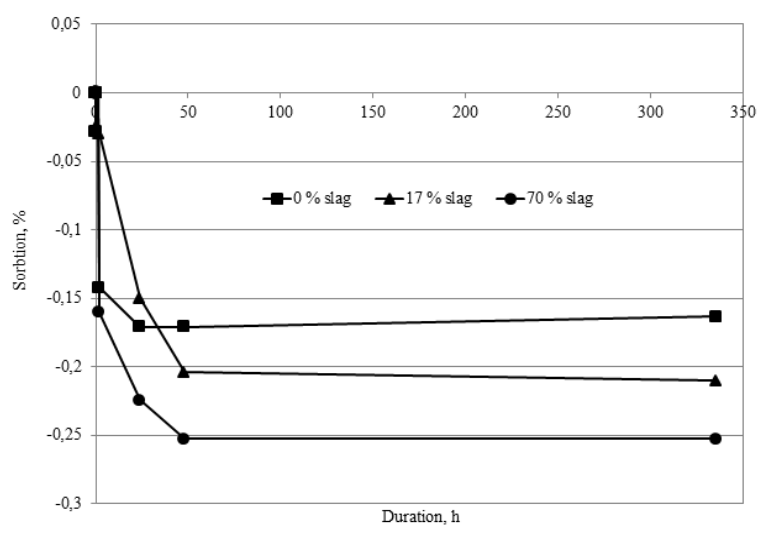

Fig. 6. Results of sorption tests of impregnated hydrotechnical concrete with different amounts of slag in cement.

More detailed sorption tests were carried out with $0 \%, 17 \%, 35 \%, 49 \%$ and $70 \%$ granular blast furnace slag content in cement constituents. Sorption tests were also performed on samples of hydrotechnical concrete in an oiled, impregnated and dried state; the results of the tests are presented in Figures 7, 8 and 9.

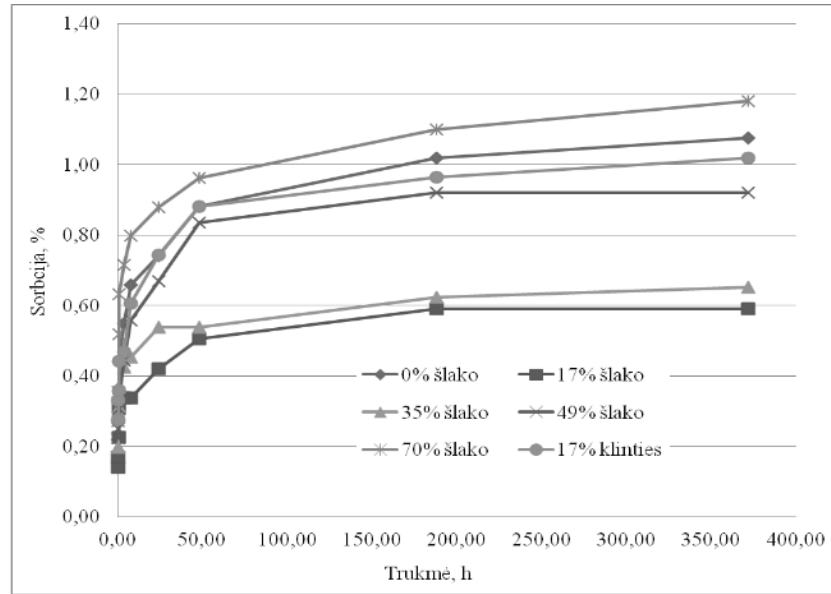

Fig. 7. Results of testing of air dried hydrotechnical concrete with different granular blast furnace slag, lime content in cement

The sorption test presented in Figure 7 shows that samples of hydrocarbon concrete with a $17 \%$ slag additive in cement have the lowest water absorption of saline solution of the Baltic Sea. After increasing the amount of granular blast furnace slag, water absorption increases with $49 \%$ granular blast furnace slag additive almost equal to water absorption without granular blast furnace slag additives, but with $70 \%$ granular blast furnace slag additive exceeds water absorption in concrete without granular blast furnace slag additives. 


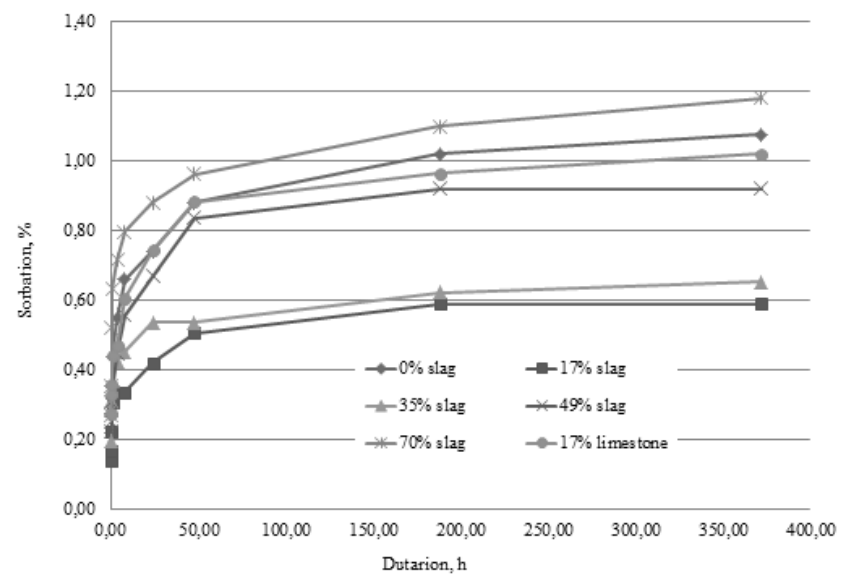

Fig. 8. Results of tests of dried hydrotechnical concrete with different granular blast furnace slag, lime content in cement (sorption)

Figure 8 shows the results of hydrotechnical concrete with different amounts of granular blast furnace slag $(0 \%, 17 \%, 35 \%, 49 \%, 70 \%)$ and lime $17 \%$ after 28 days of hardening sorption tests in a dry state. The results, which are analogous to the results found in the air dried state, show that the samples with $17 \%$ granular blast furnace slag have the lowest sorption, while the maximum sorption is observed in the samples without granular blast furnace slag additives. Samples with a $17 \%$ clay additive have a high sorption, which is almost equivalent to the sorption of samples of $70 \%$ granular blast furnace slag additives. The high sorption values of the samples show a low resistance to freezing and thawing of such concrete in a wet state.

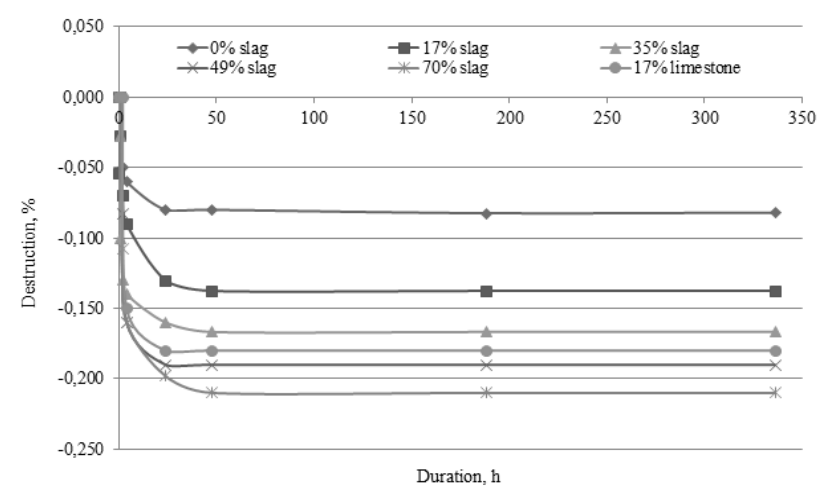

Fig. 9. Test results of impregnated hydrotechnical concrete with different granular blast furnace slag, lime content in cement (desorption)

The results of sorption of impregnated hydrocarbon concrete samples and desorption test results with different amounts of granular blast furnace slag $(0 \%, 17 \%, 35 \%, 49 \%, 70 \%)$ and $17 \%$ of rock content after 28 days of hardening sorption and desorption results are shown in Fig.9. From the results presented in Figure 9, we can see that the highest desorption is observed in concrete samples with $70 \%$ granular blast furnace slag, which is characterized by the highest sorption, and the lowest desorption is observed in samples with the granular blast furnace slag additive.

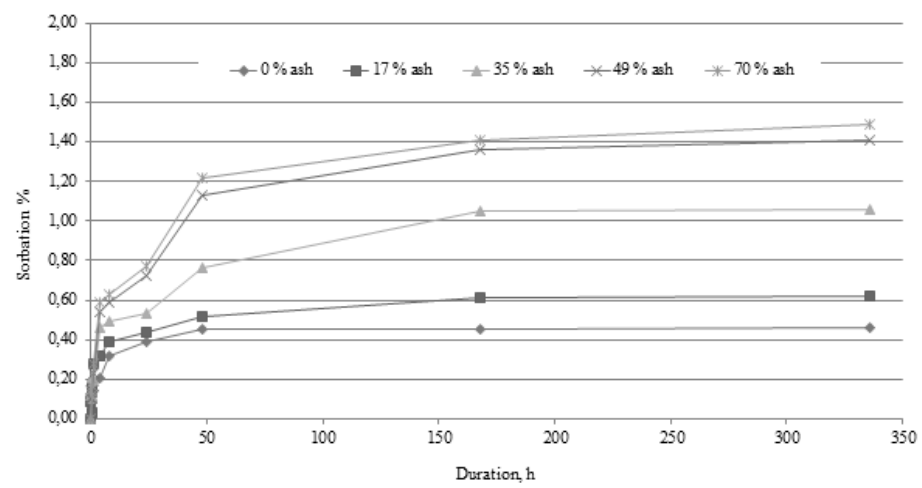

Fig. 10. Results of the sorption tests for oversized hydrotechnical concrete with ash $(0 \%, 17 \%, 35 \%, 49 \%$ and $70 \%)$ 
Figure 10 shows the results of testing hydrotechnical concrete samples with different fly ash $(0 \%, 17 \%, 35 \%, 49 \%$ and $70 \%)$ after 28 days of hardening sorption tests. As can be seen from the results presented in Figure 10, the sorption of concrete raises with the increase of the amount of the fly ash, especially when it exceeds $17 \%$. It can be concluded that the volatile ash additive increases the sorption of concrete, i.e. water absorption and thus reduces the resistance of concrete to the effects of freezing and thawing in a wet state.

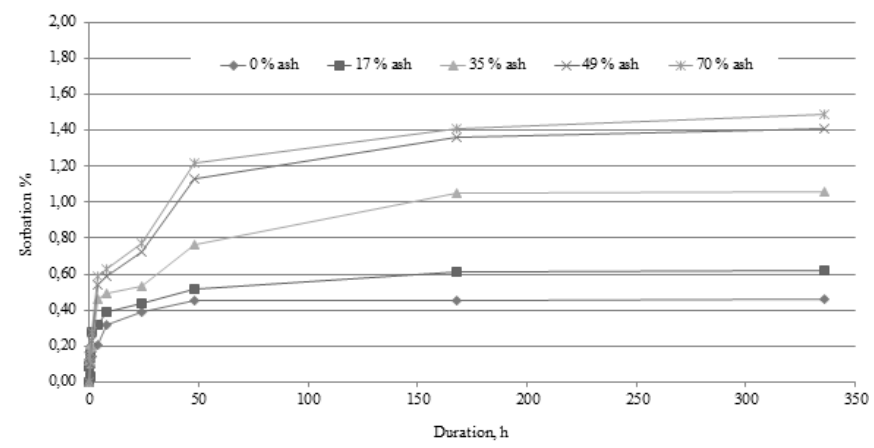

Fig. 11. Results of the sorption tests of dried hydrotechnical concrete with ash $(0 \%, 17 \%, 35 \%, 49 \%$ and $70 \%)$

Fig. 11 shows the results of a similar sorption test for dried hydrotechnical concrete samples with different fly ash content that increases the amount of concrete sorption by increasing the volumetric ash content.

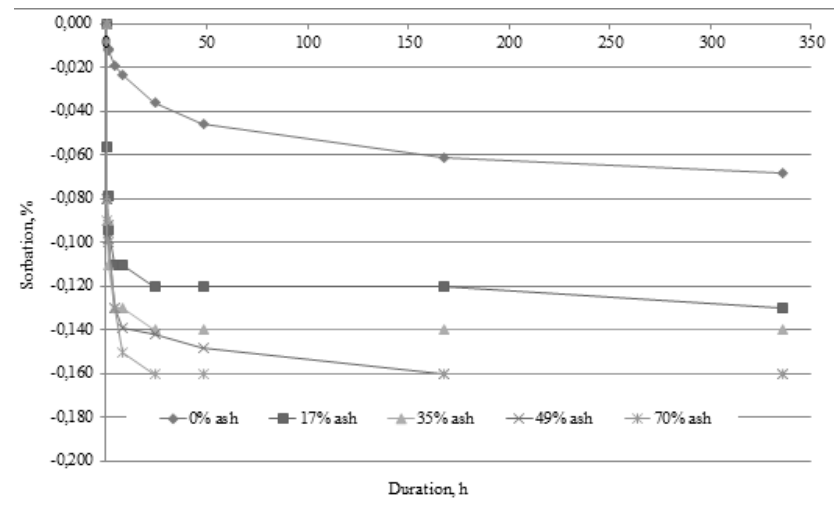

Fig. 12. Results of tests of the impregnated hydrotechnical concrete with different ash content

Figure 12 shows the results of the absorption of the impregnated hydrotechnical concrete with different fly ash content $(0 \%, 17 \%, 35 \%, 49 \%$ and $70 \%)$ in the impregnated state. The results of the research show that the highest desorption is observed in samples with $70 \%$ volatile ash content, while the lowest desorption is the samples without fly ash.

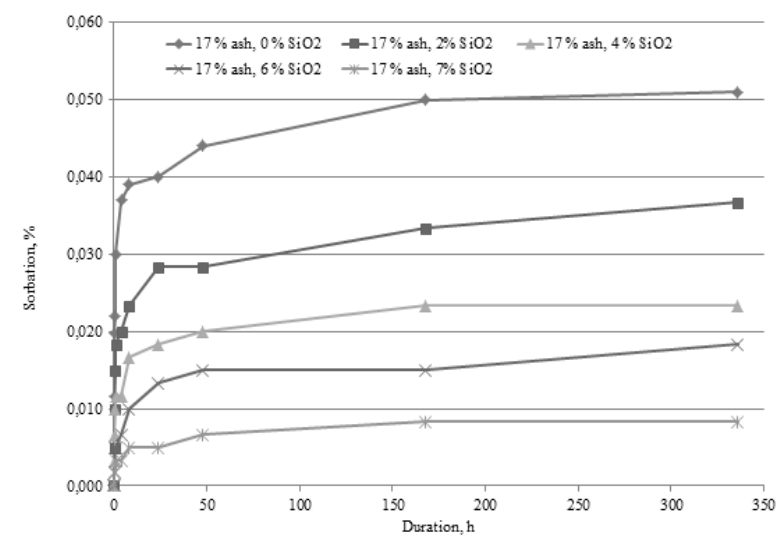

Fig. 13. Air-dried hydrotechnical concrete with $17 \%$ ash and different $\mathrm{SiO} 2$ test results 
Figure 13 shows the results of a 28-day solidification sorption test for air dried hydrotechnical concrete with $17 \%$ volatile ash and with different amounts of $\mathrm{SiO}_{2}$ micro dusts $(0 \%, 2 \%$, $4 \%, 6 \%$, and $7 \%$ ). The results obtained in Figure 13 show that with an increase in $\mathrm{SiO}_{2}$ content of micro dust up to $7 \%$ of the weight of the cement, the concrete sorption value decreases steadily. By changing the $7 \%$ cement $\mathrm{SiO}_{2}$ micro-drops, the value of sorption in concrete can be reduced from $0.05 \%$ to $0.08 \%$, i.e., about 5 times.

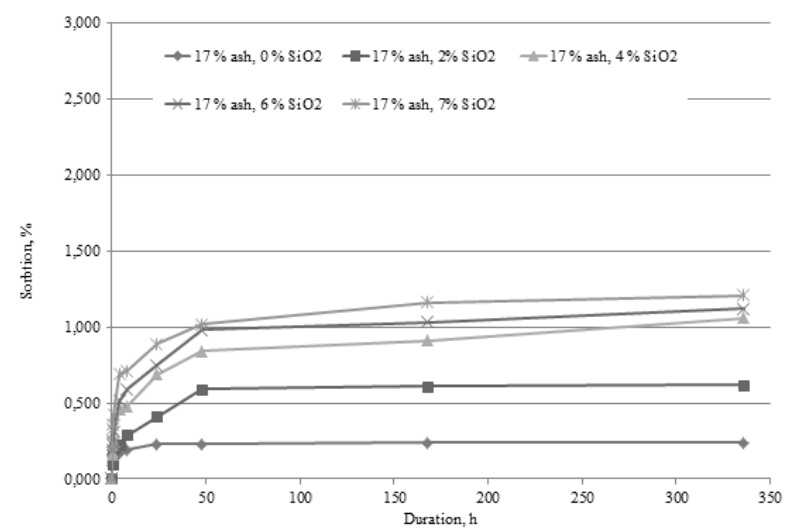

Fig. 14. Results of tests of the dried hydrotechnical concrete with $17 \%$ ash and different $\mathrm{SiO}_{2}$ content

Figure 14 shows that by increasing the amount of $\mathrm{SiO}_{2}$ microscopic materials in the cement, the concrete sorption value decreases to $7 \%$, and it decreases by approximately 5 times in the $7 \% \mathrm{SiO}_{2}$ micro dust.

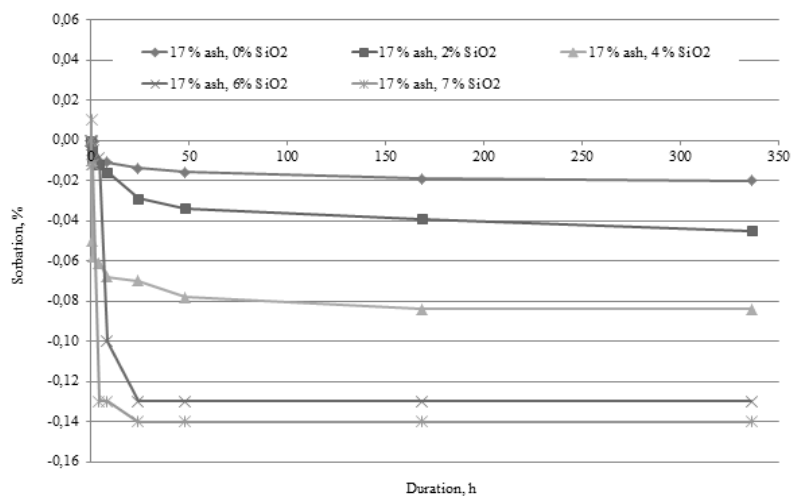

Fig. 15. Impregnated hydrotechnical concrete with $17 \%$ ash and different $\mathrm{SiO}_{2}$ test results

Figure 15 shows the results of the sorption tests for impregnated hydraulic concrete samples with a $17 \%$ volatile ash additive and with different amounts of $\mathrm{SiO}_{2}$ micro dusts $(0 \%, 2 \%, 4 \%, 6 \%$ and $7 \%)$. It can be seen from the results that the highest desorption of hydrocarbon concrete samples is characterized by a $7 \% \quad \mathrm{SiO}_{2}$ micro dust additive, and the lowest desorption is typical of samples without the addition of $\mathrm{SiO}_{2}$ micro dust.

\section{Findings of the research}

1. Visual inspection of hydrotechnical structures in Klaipeda Seaport area showed that surface decomposition of concrete is taking place, due to the operational impact of the Baltic Sea water, the processes of the Baltic Sea water sorption, which cause concrete corrosion.

2. The amounts of salts present in the Baltic Sea water, to which reinforced concrete constructions are exposed, affect the durability of the hydrotechnical concrete.

3. The impact of the Baltic Sea water is best offset by the addition of cement containing $17 \%$ to $70 \%$ and $5 \% \mathrm{SiO}_{2}$ micro dust.

4. Concrete with a slag additive from $17 \%$ to $49 \%$, replacing part of the cement, has a $43-53 \%$ lower sorption. Concrete with a $17 \%$ slag cement substitute absorbs at least the salt of the chemical composition of the Baltic Sea, and absorbs $70 \%$ of the slag additive similarly to cement without a mineral additive.

5. According to the concrete sorption - desorption parameters, it is possible to determine the durability of concrete during operation in the Baltic Sea environment. The results of concrete sorption desorption and mass loss resistance to BJA - show that the sorption rate of concrete used in such environment should not exceed $0.8 \%$ after 2 weeks. 
References

1. LST 1428.18:1997 Betonas. Bandymo metodai. Vandens igeriamumo nustatymas.

2. Martynaitis, M. Mineralinès rišamosios medžiagos. Kaunas: KPI, 1974. 294 p.

3. Wunderlich, W. O. Hydraulic structures: probabilistic approaches to maintenance. ASCE. 2005. 646 p.

4. Skominas R. Aplinkos poveikio sukeltu pažaidu itaka hidrotechnikos statiniu patikimumui ir remonto ilgaamžiškumui. Akademija. 109 p., 2008.

5. LST EN 197-1: 2011 Cementas. Idalis. Iprastiniu cementy sudetis, techniniai reikalavimai ir atitikties kriterijai. Europos standartizacijos komitetas.

6. LST EN 206:2013. Betonas. 1 dalis. Techniniai reikalavimai, savybes, gamyba ir atitiktis. Europos standartizacijos komitetas.

7. Wu, R. K., Zhang, D., Song, M. J. Properties of polymer-modified cement mortar using pre- enveloping method. Cement and concrete research. 2002. Vol. 32 Iss. 3, 425-429 p.

8. Galvonaitè ir kt. Geografija. 2012. T. 48. Nr. 2. P. 97-107. Lietuvos mokslų akademija, 2012.

9. Bukantis A. Lietuvos klimatas. Vilnius:VU leidykla. 1994. p.188.

10. Lebedeva R., Skripkiūnas G. Требования ропейскогостандарта к гидротехническому бетону, эксплуатируемому в морской среде, Проблемы современного бетона и железобетона. 2013. 5: 99-110

11. Mehta, P. K., Monteiro, P. Concrete - Structure, Properties and Materials, 2nd edh, Prentice-Hall, Englewood Cliffs, New Jersey, 1993.

12. Vektorius B., Vilkas V. Betono tvarumas. Monografija. KTU. 2006. - 156 p.

13. Skripkiūnas G. Statybiniu konglomeratu struktüra ir savybès. Vadovèlis. KTU. Vitae Litera. 2007. p. 344

14. Батраков, В. Г. Модифицированные бетоны /В.Г. Батраков. - М.: Стройиздат, 1990.- 15 с.

15. Соловьев, В. И. Эффективные модифичированные бетоны /В.И. Соловьев, Р.Б. Ергешев. - Алматы: КазГосИНТИ, 2000. $11 \mathrm{c}$.

16. Гурский, В. А. Антикоррозионная защита бетонных и железобетонных конструкиий // Материаль международной научно-практической конференции «Защита от коррозии в строительстве и народном хозяйстве» 17-19 мая 2005 г. Москва.

17. Читайшвили Т. Г., Джалагония М. Г. Защита бетонной обделки от коррозии при капиллярном переносе/ Транспортное строительство. 1988.-№1.- С.23-24.

18. Алексеев, С. Н. , Иванов, Ф. М. Модры С., Шиссль П. Долговечность железобетона в агрессивных средах. М.: Стройиздат- 1990. - $316 \mathrm{c}$.

19. Алексеев Ю. С. Н., Розенталь Н. К. Коррозионная стойкость железобетонных конструкиий в агрессивной промыциленной среде. М.: Стройиздат, 1976. -205 с.

20. Розенталь Н. К., Алексеев С. Н. Кинетика карбонизации бетона // Бетон и железобетон. 1969,- №4

21. Галимуллин Р. Г. К вопросу механизма и кинетики адсорбции / Тр. КХТИ им. Кирова. Вып. 39,- 1968.- Вып. 43.- 1969.

22. Енишерлова С. Г., Ратинов В. Б. Исследование механизма и кинетики коррозии бетона и железобетона / Сб. тр. Башниипромстроя. -Вып. 7.- 1966.

23. Минас А. И. Коррозия бетона и некоторых строительных материалов в условиях службы на засолённых грунтах в сухом климате // Труды конференции «Коррозия бетона и меры борьбы с ней».- М. Изв. АН СССР.-1954.

24. Мишутин В. А. Долговечность судостроительных бетонов и корпусов плавучих железобетонных доков, эксплуатируемыхх в морях с различными климатическими условиями.- ЦНИИ «Румб».- 1986.- 123 с.

25. Москвин В. М. Бетон для морских гидротехнических сооружений. М.: Машстройиздат, 1949.

26. Москвин В. М. Влияние обрастаний и бактериальной жизни на бетон гидротехнических сооружений. Сб. ст. НИИ по стр. Минмашстроя, М., 1949.-№1.

27. Москвин В. М., Иванов Ф. М., Алексеев С. Н., Гузеев Е. А. Коррозия бетона и железобетона. Методы их защиты.М.:Стройиздат, $1980 .-536 \mathrm{c}$.

28. Москвин В. М., Якуб Т. Ю., Васильева Т. А. и др. О диффузионной проницаемости цементного камня // Бетон и железобетон.- 1969,- № 4.- С. 1113. 